\title{
1-1 事業内容の概要
}

当財団は粉体工学の振興を目的として 7 種の助成・褒賞事業と 2 種の自主事業を実施しております。その概要 は下記の通りです。

\section{I . 助成・褒賞事業}

\begin{tabular}{|c|c|c|}
\hline No & 事業種目 & 援助等の対象 \\
\hline 1 & 研 究 助 成 & 粉体工学，粉体科学に関する研究のための助成。 \\
\hline 2 & $\begin{array}{lllll}K & O & N & A & \text { 賞 }\end{array}$ & 粉体に関する研究に従事し, 優れた研究業績を挙げた個人又はグループへの褒賞。 \\
\hline 3 & ホソカワ研究奨励賞 & 粉体工学に関する優れた若手研究者に対する集賞 \\
\hline 4 & $\begin{array}{l}\text { 学会・シンポジウム等 } \\
\text { の 開 催 援 助 }\end{array}$ & $\begin{array}{l}\text { 粉体工学に関する学会, シンポジウム等の開催費に対する緩助。学協会, 大学 } \\
\text { 等の主催者に援助。 }\end{array}$ \\
\hline 5 & 海外渡航費の援助 & 粉体工学に関する研究発表等のための海外への渡航費の援助。 \\
\hline 6 & 研究者育成の援助 & 粉体工学に関する研究に従事する大学院学生のための研究学習費の援助。 \\
\hline 7 & 出版物刊行の援助 & 粉体工学に関する出版物刊行の援助。 \\
\hline
\end{tabular}

尚，平成22年度は公募を停止いたしました。平成23年度はNo1，2，4事業を公募します。

\section{II.その他の事業（財団自主事業）}

\begin{tabular}{|c|c|}
\hline 事業の種類 & 事業内容の概要 \\
\hline $\begin{array}{l}\text { 粉体工学に関する講演 } \\
\text { 討 論 会 の 開 催 }\end{array}$ & $\begin{array}{l}\text { 粉体工学に関する重要テーマについての研究者・技術者による講演と討論の会。 } \\
\text { 年 } 1 \text { 回, 東京・大阪で隔年開催。 } \\
\text { 定員約150名, 公開。 }\end{array}$ \\
\hline $\begin{array}{l}\text { 粉体工学に関する英文 } \\
\text { 学術誌KONAの発行 }\end{array}$ & $\begin{array}{l}\text { 粉体工学に関する国際的学術誌。 } \\
\text { 年 } 1 \text { 回発行, 内容はレビュー及び研究論文約20報を含む。(約250ページ）発行部 } \\
\text { 数600部, 世界の学者, 研究者, 図書館へ無償で配布。 } \\
\text { ホームページ (http://www.kona.or.jp) に掲載。 }\end{array}$ \\
\hline
\end{tabular}

上記の諸事業は，事業年度ごとに理事会，評議員会の審議承認を得て行います。 


\section{1-2 実施状況の概要}

\section{I ．助成・褒賞事業の実施状況}

初年度以来の年次別助成等事業の実施状況は下記の通りです。

(単位：千円）

\begin{tabular}{|c|c|c|c|c|c|c|c|c|c|c|c|c|}
\hline \multirow{3}{*}{$\begin{array}{l}\text { 平成 } \\
\text { 年度 }\end{array}$} & \multicolumn{3}{|c|}{ 研究助成 } & \multicolumn{3}{|c|}{ KONA賞 } & \multicolumn{3}{|c|}{ 海外渡航者援助 } & \multicolumn{3}{|c|}{ シンポジウム等開催援助 } \\
\hline & \multirow{2}{*}{$\begin{array}{l}\text { 応募 } \\
\text { 件数 }\end{array}$} & \multicolumn{2}{|c|}{ 採 択 } & \multirow{2}{*}{$\begin{array}{l}\text { 応募 } \\
\text { 件数 }\end{array}$} & \multicolumn{2}{|c|}{ 採 択 } & \multirow{2}{*}{$\begin{array}{l}\text { 応募 } \\
\text { 件数 }\end{array}$} & \multicolumn{2}{|c|}{ 採 択 } & \multirow{2}{*}{$\begin{array}{l}\text { 応募 } \\
\text { 件数 }\end{array}$} & \multicolumn{2}{|c|}{ 採 択 } \\
\hline & & 件数 & 助成金額 & & 件数 & 助成金額 & & 件数 & 助成金額 & & 件数 & 助成金額 \\
\hline H 4 & 69 & 20 & 26,000 & 1 & 1 & 1,000 & 10 & 6 & 1,800 & 6 & 3 & 7,000 \\
\hline H 5 & 86 & 31 & 20,400 & 8 & 1 & 1,000 & 8 & 6 & 1,800 & 3 & 3 & 6,500 \\
\hline H 6 & 70 & 25 & 13,800 & 3 & 1 & 1,000 & 10 & 5 & 1,500 & 5 & 3 & 5,000 \\
\hline H 7 & 88 & 27 & 15,280 & 5 & 1 & 1,000 & 11 & 5 & 1,500 & 1 & 1 & 200 \\
\hline H 8 & 84 & 27 & 15,000 & 3 & 1 & 1,000 & 8 & 5 & 1,500 & \multicolumn{3}{|c|}{ （公募せず） } \\
\hline H 9 & 57 & 29 & 18,000 & 5 & 2 & 2,000 & 8 & 5 & 1,500 & 0 & 0 & 0 \\
\hline $\mathrm{H} 10$ & 66 & 25 & 17,800 & 5 & 2 & 2,000 & 7 & 3 & 900 & 0 & 0 & 0 \\
\hline H11 & 64 & 21 & 18,000 & 4 & 2 & 2,000 & 9 & 4 & 1,200 & 4 & 2 & 1,500 \\
\hline $\mathrm{H} 12$ & 79 & 23 & 17,900 & 4 & 2 & 2,000 & 11 & 5 & 1,500 & 2 & 2 & 1,500 \\
\hline $\mathrm{H} 13$ & 61 & 31 & 18,900 & 10 & 1 & 1,000 & 12 & 5 & 1,500 & 1 & 1 & 1,000 \\
\hline H 14 & 68 & 24 & 18,300 & 3 & 1 & 1,000 & 7 & 4 & 1,200 & 4 & 2 & 2,000 \\
\hline H 15 & 76 & 24 & 18,200 & 7 & 1 & 1,000 & 6 & 4 & 1,200 & 1 & 1 & 1,000 \\
\hline H 16 & 101 & 25 & 17,200 & 5 & 2 & 2,000 & 10 & 3 & 900 & 2 & 2 & 1,000 \\
\hline H 17 & 120 & 24 & 23,000 & 5 & 1 & 1,000 & \multicolumn{3}{|c|}{ （公募せず） } & 5 & 2 & 2,000 \\
\hline H 18 & 112 & 23 & 23,800 & 4 & 1 & 1,000 & \multicolumn{3}{|c|}{ （公募せず） } & 2 & 2 & 1,500 \\
\hline H 19 & 137 & 23 & 21,900 & 1 & 1 & 1,000 & \multicolumn{3}{|c|}{ (公募せず) } & 5 & 2 & 1,500 \\
\hline $\mathrm{H} 20$ & 128 & 18 & 13,500 & 3 & 1 & 1,000 & \multicolumn{3}{|c|}{ (公募せず) } & 4 & 3 & 1,000 \\
\hline $\mathrm{H} 21$ & \multicolumn{9}{|c|}{ 公 募 せ ず } & & & \\
\hline $\mathrm{H} 22$ & \multicolumn{9}{|c|}{ 公 募 せ ず } & & & \\
\hline $\mathrm{H} 23$ & \multicolumn{6}{|c|}{ 公募 } & \multicolumn{3}{|c|}{ 公募せず } & \multicolumn{3}{|c|}{ 公募 } \\
\hline
\end{tabular}

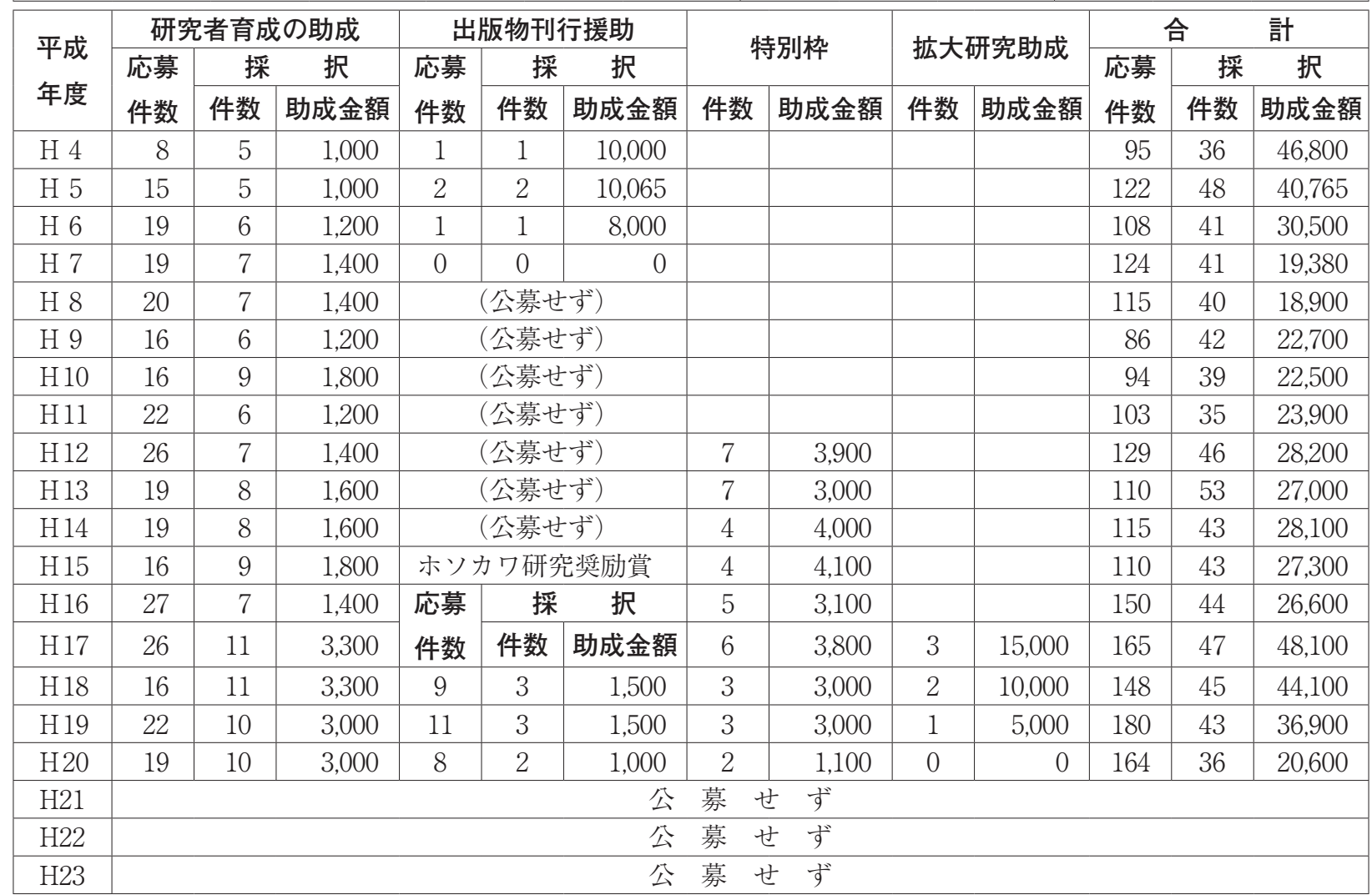




\section{II． 自主事業の実施状況の概要}

\begin{tabular}{|c|c|c|c|c|c|c|c|c|c|}
\hline \multirow{2}{*}{$\begin{array}{l}\text { 平成 } \\
\text { 年度 }\end{array}$} & \multicolumn{5}{|c|}{ 粉体工学に関する講演討論会 } & \multicolumn{4}{|c|}{ KONA誌の発行 } \\
\hline & 回数 & 討論会テーマ & 講演数 & 出席者 & 経費 & 号数 & 総頁数 & 発行部数 & 経費 \\
\hline H 7 & 第29回 & 粉体プロセスにお打る安全·健康問題 & 5 & 232 & $336^{\text {万 }}$ & No.13 & 240 & 2300 & $773^{\text {万 }}$ \\
\hline H 8 & 第30回 & 先端機能性材料の製造プロセス & 5 & 144 & $255^{\text {万 }}$ & No.14 & 200 & 2300 & $749^{\text {万 }}$ \\
\hline H 9 & 第31回 & 環境保全技術と粉体工学 & 6 & 142 & $375^{\text {万 }}$ & No.15 & 254 & 2200 & $750^{\text {万 }}$ \\
\hline H 10 & 第32回 & $\begin{array}{l}\text { 最近の造粒と粒子設計－医療品／食品製造 } \\
\text { プロセスを中心として- }\end{array}$ & 6 & 210 & $463^{\text {万 }}$ & No.16 & 256 & 2200 & $819^{\text {万 }}$ \\
\hline $\mathrm{H} 11$ & 第33回 & 新産業創出のための粉体工学 & 6 & 246 & $414^{\text {万 }}$ & No.17 & 250 & 2200 & $744^{\text {万 }}$ \\
\hline $\mathrm{H} 12$ & 第34回 & I T産業における粉体工学 & 8 & 283 & $513^{\text {万 }}$ & No.18 & 248 & 2200 & $716^{\text {万 }}$ \\
\hline $\mathrm{H} 13$ & 第35回 & ナノ粒子材料への期待 & 7 & 184 & $375^{\text {万 }}$ & No.19 & 283 & 2200 & $799^{\text {万 }}$ \\
\hline $\mathrm{H} 14$ & 第36回 & ナノ粒子の産業界への展開 & 6 & 208 & $416^{\text {万 }}$ & No.20 & 276 & 2200 & $792^{\text {万 }}$ \\
\hline H 15 & 第37回 & ナノパーティクル・テクノロジー & 6 & 227 & $510^{\text {万 }}$ & No.21 & 246 & 1300 & $1300^{\text {万 }}$ \\
\hline $\mathrm{H} 16$ & 第38回 & ナノ構造制御による粉体産業の発展をめざして & 6 & 160 & $450^{\text {万 }}$ & No.22 & 211 & 700 & $866^{\text {万 }}$ \\
\hline H 17 & 第39回 & ここまで来たナノ粒子の実用化 & 7 & 205 & $538^{\text {万 }}$ & No.23 & 224 & 1000 & $1007^{\text {万 }}$ \\
\hline H 18 & 第40回 & $\begin{array}{l}\text { ナノテク実用化の鍵を握るナノ粒子の制御 } \\
\text { と応用 }\end{array}$ & 6 & 174 & $532^{\text {万 }}$ & No.24 & 252 & 1000 & $1309^{\text {万 }}$ \\
\hline H 19 & 第41回 & $\begin{array}{l}\text { ナノパーティクル・テクノロジー：新市場 } \\
\text { 開拓と参入 }\end{array}$ & 6 & 167 & $438^{\text {万 }}$ & No.25 & 303 & 1000 & $1146^{\text {万 }}$ \\
\hline $\mathrm{H} 20$ & 第42回 & $\begin{array}{l}\text { ナノパーティクル・テクノロジー：応用· } \\
\text { 実用化への新展開 }\end{array}$ & 6 & 126 & $340^{\text {万 }}$ & No.26 & 282 & 1000 & $804^{\text {万 }}$ \\
\hline $\mathrm{H} 21$ & 第43回 & $\begin{array}{l}\text { ナノテクノロジーによる粉体の機能化と新 } \\
\text { 材料開発 }\end{array}$ & 6 & 160 & $313^{\text {万 }}$ & No.27 & 248 & 600 & $625^{\text {万 }}$ \\
\hline H22 & 第44回 & $\begin{array}{l}\text { ナノパーテイクルハンドリング技術が生み } \\
\text { 出す新材料 }\end{array}$ & 6 & 134 & $266^{\text {万 }}$ & No.28 & 242 & 600 & $385^{\text {万 }}$ \\
\hline
\end{tabular}

\section{(第44回粉体工学に関する講演討論会}

テーマ：ナノパーティクルハンドリング技術が産み出す新材料

日時：2010年 9 月 6 日（月）

場所：東京ガーデンパレス（東京都文京区湯島1-7-5）

（セッション 1) （司 会） 同志社大学教授 日高 重助

講演 1 「コロイドプロセスの高度化による高次構造セラミックスの創製」

物質・材料研究機構 ナノセラミックスセンター長

目義 雄

講演 2 「ナノ粒子複合化による固体高分子形燃料電池の低白金化技術開発」

（セッション 2) （司 会） 京都大学 特命教授 東谷 公

首都大学東京 都市環境科学研究科 助教 棟 方 裕一

講演 3 「ナノ粒子分散系の粘弾性設計と機能性流体への応用」

大阪大学 接合科学研究所 准教授 阿 部 浩 也

講演 4 「スラリー特性制御によるセラミックスの構造制御と高機能化」

（セッション 3 ）（司 会） 大阪大学 教授 内藤 牧男

(株)村田製作所 材料開発統括部 部長 中 村 一 郎

講演 5 「ナノ構造制御技術による化粧品用高機能材料の開発」

花王株式会社 加工・プロセス開発研究所 グループリーダー 峯 浩 二

講演 6 「ナノ粒子分散・複合化プロセスの開発と先進消防服などへの応用展開」

ホソカワミクロン(株) 粉体工学研究所 所長 横 山 豊 和 


\section{○粉体工学に関する英文誌KONA No.28の発行}

KONA誌の編集は粉体技術談話会に委託され，粉体技術談話会はKONA編集委員会を組織して編集に当った。 この委員会はアジア，ヨーロッパ，アメリカに各ブロックの編集委員会を設け，それぞれの地域より優れた粉体 関係の論文 (レビュー, 研究報告) を集め, これを編集して年 1 回，KONA誌として出版している。本年度 (2010) はKONA No.28として平成22年12月25日に発行された。

掲載論文数は 16 編で，内訳はアジアブロックから 5 篇，ヨーロッパブロックから 6 篇，アメリカブロックから 5 篇が寄稿されている。

本年は600部を世界中の粉体関係の研究者，図書館，大学等に寄贈し高い評価を得ている。

なお，No.20以降は全記事を，http://www.kona.or.jp で無料で閲覧することができる。 